\section{HUevist国}

\author{
CARTA AO EDITOR
}

\title{
Preocupações quanto ao desconhecimento de profissionais de odontologia em relação à anemia falciforme
}

Concerns about the lack of knowledge of dental professionals regarding sickle cell anemia

Sabrine Teixeira Ferraz Grünewal ${ }^{1}$ Thiago Grünewal

Em seu artigo "Avaliação do conhecimento sobre a doença anemia falciforme: sob a ótica da odontologia", Araújo e colaboradores apresentam um estudo transversal com estudantes de odontologia e cirurgiões dentistas graduados, no qual os mesmos autoavaliaram o conhecimento que possuíam sobre a anemia falciforme. Os resultados mostraram que, apesar de grande parte dos participantes reconhecer a importância do tema, muitos revelaram pouco conhecimento sobre a doença e admitiram a necessidade de uma maior inserção do assunto durante a graduação e em eventos científicos. ${ }^{1}$

A doença falciforme é uma das doenças genéticas e hereditárias mais comuns do mundo, afetando, no Brasil, majoritariamente as populações negra e parda. ${ }^{2}$ Os pacientes com doença falciforme podem apresentar uma ampla variedade de manifestações sistêmicas, destacando-se a anemia crônica, os episódios dolorosos causados por vaso-oclusão, e o risco aumentado para infecções. ${ }^{2}$ Do ponto de vista da saúde bucal, podem ser observados atraso na erupção dentária, periodontite, hipoplasia e opacidade dentária, hipomineralização do esmalte e dentina, maior risco para cáries, doença periodontal, e perda dentária por necrose pulpar. ${ }^{1,2}$

Além disso, sabe-se que pacientes com doença falciforme podem evoluir com complicações vaso-oclusivas mediante a situações de estresse orgânico: durante quadros infecciosos, em estados de hipoxemia ou desidratação, ou quando realizam procedimentos cirúrgicos e/ou indução anestésica. ${ }^{3}$ Assim, é importante que essas situações sejam evitadas sempre que possível.

Nesse contexto, a prevenção de agravos em saúde bucal parece ser a chave para a promoção da saúde desses pacientes. Pacientes com o diagnóstico e seus familiares precisam receber a educação em saúde apropriada, e os profissionais de odontologia têm um papel crucial para a conscientização quanto às formas de prevenção, tratamento, cuidado e autocuidado. ${ }^{2}$ Assim, é preocupante que, no estudo de Araújo e colaboradores, apenas $8 \%$ dos cirurgiões dentistas e $0,5 \%$ dos graduandos em odontologia tenham respondido que já haviam atendido pacientes com anemia falciforme. ${ }^{1}$ Esse dado provavelmente reflete uma dificuldade de acesso aos serviços de odontologia no país, especialmente no ambiente do Sistema Único de Saúde (SUS), onde os atendimentos odontológicos disponibilizados são fre- quentemente insuficientes para a demanda da população, e geralmente focados no tratamento de doenças e complicações já instaladas, mais do que em ações de prevenção e promoção da saúde.

A Associação Brasileira de Hematologia, Hemoterapia e Terapia Celular ( $\mathrm{ABH})$ promove, anualmente, um congresso nacional em que parte da carga horária é dedicada a eventos multidisciplinares, incluindo a odontologia, além de contar com um Comitê de Odontologia permanente. Entretanto, isso não parece ser suficiente para que a importância dessa e de outras doenças hematológicas seja divulgada entre os profissionais. Seria importante articular parcerias para que, em eventos científicos específicos da área de odontologia, houvesse espaço para a educação profissional na área de hematologia. Aliás, embora não tenha sido o tema avaliado nessa publicação, é possível que esse mesmo padrão se repita para outras doenças crônicas de importância para a saúde pública.

Araújo e colaboradores também trazem, em seu artigo, um quadro de resumo das principais recomendações para o atendimento de pacientes com anemia falciforme por profissionais de odontologia. ${ }^{1}$ Seria desejável que essas informações mínimas, porém valiosas, fossem divulgadas aos serviços de atendimento e estivessem facilmente disponíveis, evitando equívocos de conduta facilmente evitáveis e garantindo a segurança do atendimento desses pacientes. O Ministério da Saúde também publicou um Manual de Saúde Bucal na Doença Falciforme, com informações mais detalhadas, disponível gratuitamente. As informações, portanto, estão disponíveis; o que ainda falta é o reconhecimento da importância dessa doença em termos de formação profissional multidisciplinar.

\section{REFERÊNCIAS}

1. Araújo LB, Andrade ALF, Buffon MCM, Pizzatto E. Avaliação do conhecimento sobre a doença anemia falciforme: sob a ótica da odontologia. HU Rev. 2020; 46:1-9.

2. Ministério da Saúde (BR). Doença falciforme: saúde bucal: prevenção e cuidado. Brasília: Ministério da Saúde; 2014. 
3. Ministério da Saúde (BR). Doença falciforme: condutas básicas para o tratamento. Brasília: Ministério da Saúde; 2014.

${ }^{1}$ Faculdade de Medicina, Centro Universitário Atenas, Brasil.

${ }^{2}$ Faculdade de Odontologia, Pontifícia Universidade Católica de Minas Gerais, Brasil.

\section{$\bowtie$ Sabrine Grünewald}

Av. Eugênio do Nascimento, s/n, Dom Bosco, Juiz de Fora, Minas Gerais CEP: $36038-330$

円 sabrine.pediatria@gmail.com 